\title{
Comparison of the Pathomorphological and Immunohistochemical Findings of an Experimental Co-infection with Infectious Bronchitis Virus M-41 and Bordetella Avium in Chicks
}

\author{
Mehmet Fatih BOZKURT ${ }^{*}$, Günay ALÇIĞIR² \\ ${ }^{1}$ Afyon Kocatepe University, Faculty of Veterinary Medicine, Department of Pathology, 03100, Afyonkarabisar, Turkey \\ ${ }^{2}$ Ankara University, Faculty of Veterinary Medicine, Department of Pathology, 06130, Ankara, Turkey
}

\begin{abstract}
In this experimental study, our objective was to investigate the macroscopic, microscopic and immunohistochemical findings developed in the respiratory system due to the co-infection with infectious bronchitis virus (IBV) M-41 and the commensal Bordetella avium in the respiratory tract in 15-day-old female Brown-Nick chicks. In this study, a total of 70 non-SPF, healthy chicks were randomized into 4 groups. The chicks in Group $1(\mathrm{n}=20)$ were infected only with IBV-M41 strain; chicks in Group $2(\mathrm{n}=20)$ were infected with IBV-M41 and B. avium; chicks in Group $3(\mathrm{n}=20)$ were infected only given B. avium. Group 4 ( $\mathrm{n}$ $=10$ ) were given sterile physiological saline at the same dose and route. The administration of the strains was performed with an intranasal injection. On the 2nd-7th., 9th, 11th, 13th, 15th, and 18th days of the post-inoculation, 2 chicks from the experimental groups and 1 chick from the control group were sacrificed. In Group 1, the degenerative and inflammatory changes, which were observed in the 2 nd day of infection, disappeared on the 15 th day. In Group 2, we noticed bacterial colonies and mucous exudate containing heterophile leukocytes in the lumens of trachea and larynx. Starting from the 13th day, findings related to recovery e.g., in Group 1 were noticed. In the microscopical examination of the tissues by immunohistochemistry and immunofluorescent methods, we observed the antigenic distribution in the upper respiratory tract in Group 1 between the 2nd and 5th days and in Group 2 between the 2nd and 9th days. However, lungs were involved between the 5th and 11th days in Group 1 and between the 7th and 11th days in Group 2. In conclusion, we determined that the progress of findings was relatively milder in chicks primarily infected with IBV-M41and the findings lasted longer in chicks co-infected with B. avium and IBV caused severe symptoms in chicks in case of co-infection.
\end{abstract}

Keywords: IBV-M41, Bordetella avium co-infection, experimental, pathology, chick.

\section{Civcivlerde Enfeksiyöz Bronşitis Virusu M-41 Suşu ve Bordetella Avium ile Oluşturulan Deneysel Koenfeksiyonunda Patomorfolojik ve İmmunohistokimyasal Bulguların Karşılaştırılması}

\section{ÖZ}

Bu deneysel çalışmada, enfeksiyöz bronşitis virusu (IBV) M-41 suşu ve solunum kanalı kommensali olan Bordetella avium 15 günlük Brown-Nick 1rkı yumurtacı dişi civcivlere verilerek koenfeksiyon oluşturulmuş; solunum sisteminde gelişen makroskobik, mikroskobik ve immunohistokimyasal bulguların ortaya çıkarılması amaçlanmıştır. Çalışmada 70 adet non-SPF, sağlıklı civciv rastgele 4 farklı gruba ayrıldı. Grup 1'e $(\mathrm{n}=20)$ yalnız IBV-M41 suşu; Grup 2'ye(n=20) IBV-M41 suşu ve B. avium; Grup 3'e $(\mathrm{n}=20)$ yalnız B. avium nazal yoldan $0.1 \mathrm{ml}$ verilerek civcivler enfekte edildi. Kontrol grubu olan Grup 4'teki hayvanlara $(\mathrm{n}=10)$ ise aynı doz ve yoldan yalnızca steril fizyolojik tuzlu su verildi. Enfeksiyonun 2.-7.,9.,11.,13.,15. ve 18. postinokulasyon günlerinde her bir gün için deney gruplarından 2; kontrol grubundan 1 hayvan alınarak ötenazileri gerçekleştirildi. Grup 1'de enfeksiyonun 2. gününde trakea ve larinkste görülen dejeneratif ve yangısal değişiklikler 15. günde ortadan kalkmıştı. Grup 2'deki hayvanlarda ilk gruba ek olarak trakea ve larinks lümenlerinde heterofil lökositler içeren müköz eksudat ile bakteri kolonileri de fark edildi. 13. günden sonra öncekine benzer şekilde iyileşmeye yönelik bulgular dikkati çekti. Grup 3 ve 4' de herhangi bir bulguya rastlanmadı. İmmunohistokimya ve immunfloresan yöntemleriyle dokularda antijenik dağılımın Grup1'de 2-5.; Grup-2'de 2-9. günlerde üst solunum kanalındayken, Grup-1'de 5-11.; Grup-2'de 7-11. günlerde akciğerde lokalize olduğu gözlendi. Sonuç olarak IBV ile primer enfekte civcivlerde bulguların daha hafif seyrettiği, B. avium’la koenfete civcivlerde bulguların daha şiddetli ve uzun sürdüğü, IBV'nin koenfeksiyonla daha şiddetli bulgular gösterdiği belirlenmiştir. Anahtar Kelimeler: IBV-M41, Bordetella avium ko-enfeksiyon, deneysel, patoloji, civciv

To cite this article: Bozkurt. M.F. Alçğr. G. Comparison of the Pathomorphological and Immunobistochemical Findings of an Experimental Co-infection with Infectious Bronchitis Virus M-41 and Bordetella Avium in Chicks. Kocatepe Vet J. (2021):14(1):137-148

Submission: 23.11.2020 Accepted: 26.02.2021 Published Online: 28.02.2021

ORCID ID; MFB: 0000-0002-1669-0988, GA: 0000-0002-3001-6420

*Corresponding author e-mail: fbozkurt@gmail.com 


\section{INTRODUCTION}

Infectious bronchitis (IB) disease, caused by the highly contagious Infectious Bronchitis Virus (IBV) in chickens, has an acute course and serious epidemics in animals of almost all ages. This virus leads to lesions not only in the respiratory tract but also in the urogenital tract in chicks (Cavanagh and Gelb 2008, Liu et al 2015). Although it does not usually end up with death, it causes important losses depending on retarded growth, reduced egg yield, and egg quality. IBV is classified in the Coronaviridae family under the Gammacoronavirus genus (Cavanagh and Naqi 2003, King et al 2012). Until today, more than 26 serotypes and 1652 strains (For example T, Holland, Connecticut, Arkansas strains, 793/B, IB2, H120, IBVPR-05, nephropathogenicIBvar2 strain) were determined. The course of the disease and the involvement of the organs depends on the strains causing the infection. The renal symptoms are usually mild in strains causing respiratory tract infections, while the findings related to the respiratory system are mild or absent at all in infections caused by the nephropathogenic strains (Mcmartin 1993, Cavanagh and Naqi 2003, Benyeda et al 2010, King et al 2012, Fernando et al 2013, Liu et al 2015, Valastro et al 2016). The antigenic properties of the Massachusetts strain (M-41), which is particularly active in the respiratory system, are currently considered as the prototype (Mcmartin 1993, Cavanagh 2003).

The experimental infections caused by the IBV Massachusetts serotype H-13 strain showed that chicks in older ages were also affected and exudate changing form seromucous to fibrinous composition emerged in the nose, trachea, and air sacs along with the urinary system findings (Butcher 1990).

In IBV infections, the lesions are relatively more severe in the presence of secondary or mixed infections (Kinde et al 1991). Co-infections are caused especially by Escherichia coli and Mycoplasma gallisepticum. Coinfections of IBV and E. coli cause exudates changing between serous and caseous character in the nose and sinuses, petechial hemorrhage in the trachea and bronchial mucosa and sometimes severe findings in the air sacs. Fibrin accumulation in the abdominal air sac is one of these severe changes (Smith et al 1985, Schulz 1991, Jackwood and Wit 2013, Bwala et al 2018).

Bordetella avium is a Gram-negative, mobile, and nonfermentative coccobacillus. Bordetellosis is a very contagious upper respiratory tract disease caused by $B$. avium (Jackwood and Saif 2003). This disease is characterized by eye-nose discharge, sneezing, respiratory distress (dyspnea), tracheal collapse, and weight loss (Arp and Cheville 1984). The infection caused by B. avium in young turkeys characterized by upper respiratory tract lesions is called turkey coryza (B. avium rhinotracheitis) (Jackwood and Saif 2003). Flocks, particularly quails are sensitive to B. avium in changing levels. This pathogen that can cause opportunistic infections in chicken (Jackwood et al 1995) is activated by the primary infections affecting the respiratory system or other factors. For example, bordetellosis could be developed after the exposure of irritating agents like ammonia, and vaccination with infectious bronchitis (IB) or Newcastle disease. B. avium, which is an opportunistic and commensal pathogen, may cause severe infections when it is concomitant with infectious bronchitis disease (Blackall and Doheny 1987, Jackwood et al 1995, Odubgo et al 2006).

Our objective in this study was to describe the mixed infections with Massachusetts (M-41) strain, which is considered as the reference of IBV, and the opportunistic pathogen B. avium seen in the flocks, to compare the positive and negative control groups in order to investigate the course of primary IB in chicks and to investigate the effects of $B$. avium on this condition and consequently to elucidate the pathogenesis of IB disease.

\section{MATERIALS AND METHODS}

\section{Supply of the experimental animals and legal permissions}

This study was conducted with seventy healthy 15 -dayold Brown Nick female layer chicks that were supplied by a disease-free poultry company. The study was approved by the Local Ethics Committee of the Veterinary Faculty at Ankara University dated May 23 2006 and numbered 2006/23.

\section{Inoculum Implementation}

In this study, we used IBV-M41 strain with a 50\% embryo infectious dose (EID50) $(106.4 / \mathrm{ml})$ in SPF eggs according to Reed and Muench (1939) method, which were obtained from the Manisa Poultry Diseases Research and Vaccine Production Institute. The standard B. avium strain used in this study was obtained from Dr. Y.M. Saif (Food Animal Health Research Program Wooster, Ohio, USA) and this standard B. avium strain was cultivated in the sheep blood agar under aerobic conditions at $37^{\circ} \mathrm{C}$ for 48 hours. The total count method for live bacteria (Bilgehan, 2004) was adjusted to a concentration of $107 \mathrm{CFU} / \mathrm{ml}$ in the Pertussis Reference Laboratory at Refik Saydam Hifzısihha Center.

\section{Hyperimmune Serum}

The rabbit anti-IBV-M41 strain hyperimmune serum (1/32 HI titration), which was obtained from the Manisa Poultry Diseases Research and Vaccine Production Institute, was used for the immunohistochemical examinations.

\section{Experiment Groups and Procedure}

After the chicks became 15 days old, they were divided into groups according to the single or combined inoculation of the strains and they were infected with inoculums as described in the literature (Arp and 
Cheville 1984, Nakamura et al 1996, Jackwood and Saif, 2003). Group 1: Twenty 15-day-old chick were inoculated through the intranasal route only with IBVM41 strain (EID50 106.4/ml; 0.1ml). Group 2: Twenty 15-day-old chicks were inoculated through the intranasal route with IBV-M41 strain (EID50 $106.4 / \mathrm{ml} ; 0.1 \mathrm{ml})$ like in Group 1 and B. avium (107 $\mathrm{CFU} / \mathrm{ml} ; 0.1 \mathrm{ml})$. Group 3: Twenty15-day-old chicks were inoculated through the intranasal route only with B. avium (107 CFU/ml; 0.1ml). Group 4: Ten 15-dayold chicks were reserved in the control group and all received $0.1 \mathrm{ml}$ saline solution through the intranasal route. On the 15th day of the experiment, blood samples were taken from 5 chicks from each group and hemagglutination-inhibition (HI) test was carried out and the presence of maternal antibody for IBV-M41 strain in the blood of chicks was examined. None of the chicks died during the infection period.

\section{Necropsy Assessment}

Two of the chicks were randomly chosen from each group on the 2nd, 3rd, 4th, 5th, 6th, 7th, 9th, 11th, 13th, 15th, and 18th days, were anesthetized with 5.5$11 \mathrm{mg} / \mathrm{kg}$ pentothal (Thiopental sodium pentothal, I.E. Ulagay Ilaç Sanayii Turk A.Ş. Topkapı, Istanbul, Turkey) and sacrificed with cervical dislocation via a single manipulation of the dorsal cervical region. Systemic necropsy was carried out following euthanasia.

\section{Histopathological Examinations}

After the necropsy, tissue samples were taken from all organs (mainly nose, larynx, air sacs, trachea, and lungs) and referred to histopathological examination. The obtained samples were fixed in a $10 \%$ neutral formalin solution ( $\mathrm{pH}$ 7.2-7.4). Following routine tissue care, 4-5 micron thick sections were cut with a microtome from the prepared paraffin blocks and stained with the hematoxylin-eosin (HE) method (Luna, 1968).

\section{Antigenic Determination in Tissue \\ Indirect immunoperoxidase method}

$\mathrm{IB}$ virus antigens were detected in the tissue with the avidin-biotin-peroxidase complex peroxidase (ABC-P) method. For this purpose, 4-5 micron thick sections that are cut from the routinely prepared paraffin blocks were transferred on the adhesive glass slides. Deparaffinized and rehydrated sections were washed with phosphate-buffered saline (PBS). Then the sections inserted into the humidity cabinet and kept in the $0.1 \%$ trypsin solution at $37^{\circ} \mathrm{C}$ for 30 minutes to unveil the antigenic structures. Samples were washed in PBS three times for 5 minutes. Then they were placed in the 3\% hydrogen peroxidase solution for reduce the endogenous peroxidase activity. The tissues were washed again with PBS. Then they were processed with normal goat serum at $37^{\circ} \mathrm{C}$ for 20 minutes to prevent the non-specific antibody reactions. Afterwards, the serum was removed and rabbit anti-IBV primary antibody (diluted at $1 / 16$ ) was dripped without washing. The samples were incubated in the incubator at $37^{\circ} \mathrm{C}$ for 30 minutes. Then the samples were washed with PBS 3 times for 5 minutes each. Following this procedure, biotinized goat antirabbit secondary antibody (Rabbit ExtrAvidin Peroxidase Kit, Sigma-EXTRA3) was dripped on the tissues and incubated in the incubator at $37^{\circ} \mathrm{C}$ for 20 minutes. Then, the samples were washed with PBS and incubated in the incubator at $37^{\circ} \mathrm{C}$ for 20 minutes following the dripping of streptavidin-peroxidase complex (Rabbit ExtrAvidin Peroxidase Kit, SigmaEXTRA3) on the samples. Following this final incubation, the samples were washed again with PBS and processed with substrate-chromogen (AEC chromogen kit, Sigma AEC-101) to activate the reaction. The reaction in the tissue sections was controlled at room temperature under the microscope for 1-10 minutes. After the emergence of the desired color, the reaction was terminated under distilled water. Mayer's hematoxylin was applied to the sections for 30 seconds to stain the background. At the end of the process, the glass slides were covered with a lamella via a water-based adhesive. In the control sections, PBS was used instead of the primary antibody and the following processes were carried out according to the abovementioned procedure.

\section{Indirect immunofluorescence (IF) method}

The tissues obtained from the sacrificed chicks were prepared for staining with the Sainte-Marie technique (1962).4-5mm-thick tissues, which were obtained from the organs of the respiratory system for this purpose, were kept in a $96 \%$ ethyl alcohol solution at $4^{\circ} \mathrm{C}$ for one hour. The tissues were cut at $2-3 \mathrm{~mm}$ thickness and placed in the cassettes. All cassettes were processed as described in Sainte-Marie technique (1962) and tissues were embedded on paraffin blocks. The paraffin blocks were stored in the refrigerator until the cutting process with the microtome. The sections that were transferred on the glass slides were deparaffinized and rehydrated with xylene and alcohol respectively at $4^{\circ} \mathrm{C}$ before the staining with the immunofluorescence method. The sections were then transferred into PBS and prepared for the staining with the immunofluorescence method. The sections, which were placed in the humidity cabinet, were incubated with rabbit anti-IBV primary antibody (diluted 1/16) in the incubator at $37^{\circ} \mathrm{C}$ for 30 minutes. After the incubation, the samples were washed with PBS three times for 5 minutes each. Then goat anti-rabbit serum (conjugate, Sigma- F 0382) (diluted 1/16) bound with fluorescein isothiocyanate (FITC) was dripped on the tissue sections. The samples were transferred again into the incubator at the same temperature for the same duration. After the second incubation, 1 drop of $10 \%$ glycerinated PBS was applied onto the sections and then they were covered with a lamella. The edges of the lamella were coated with paraffin and the 
samples were stored in the refrigerator until the examination time.

\section{Photomicrography}

The examination of the fields stained with the histopathological and immunoperoxidase method was done under the DM-4000B digital light microscope and the pictures were taken with a Leica DFC-280 camera attachment. Regarding the immunofluorescence method, the examination of the sections was performed with a fluorescence microscope (overhead lighting) (Leitz Laborlux D, BP 450-490 wavelength filter system, mercury vapor, darkfield microscope).

\section{FINDINGS}

\section{Macroscopic Findings}

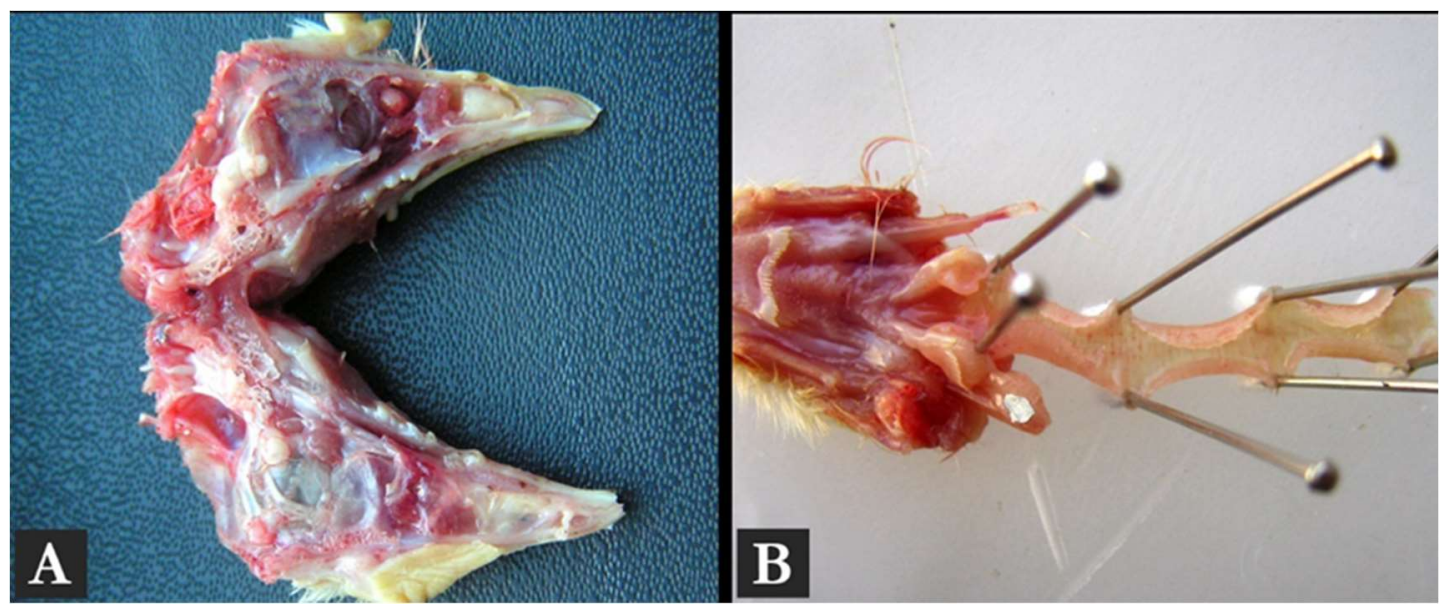

Figure 1: Group 1; hyperemia and edema in the mucosa of the nose (A) and larynx and trachea (B) on the 5th day of infection.

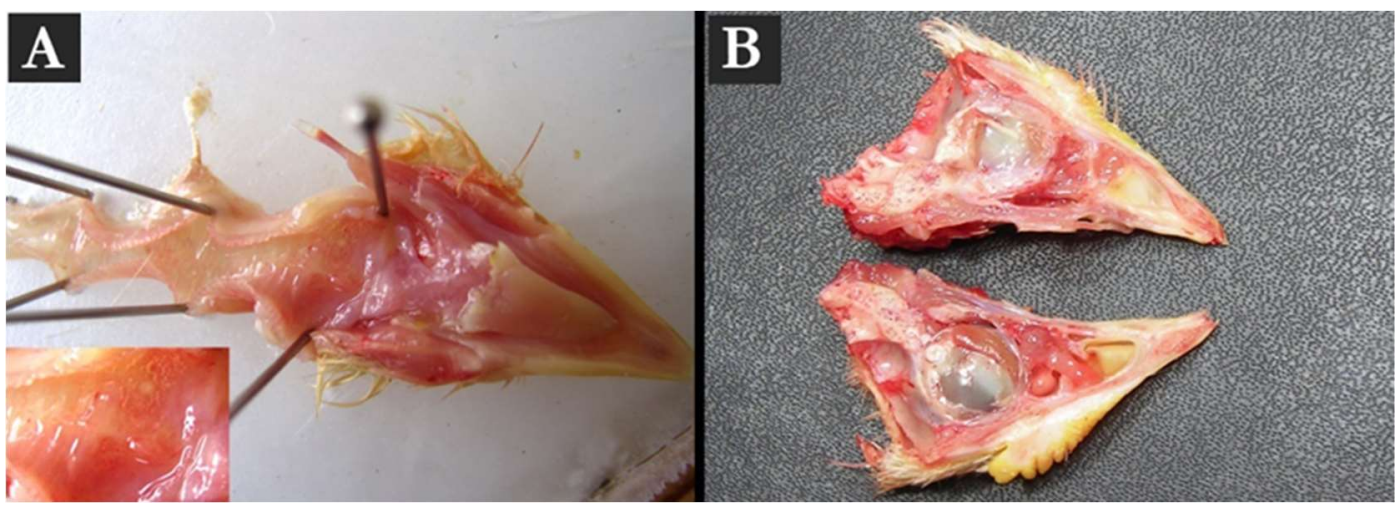

Figure 2: Group 2; severe hyperemia in the nasal mucosa (A) and seromucous exudate in the laryngeal and tracheal mucosa (B) (B small frame) on the 5 th day of infection. 


\section{Histopathological Findings}

Findings In Group 1, there were lymphocyte infiltration, hemorrhage and focal lymphoid foci in the mucosa. In group 2, they were in the form of cell debris, lymphoid cell infiltration, dense heterophile leukocyte infiltrations and hemorrhages on the mucous membranes of the organs. All findings related to the nasal mucosa, larynx, and trachea and partially lungs observed in Group 1 and 2 were summarized in Table 1 according to the groups (Figure-3). We did not observe any microscopic finding in Group 3 and Group 4 (the control group), which was consistent with the macroscopic examination.

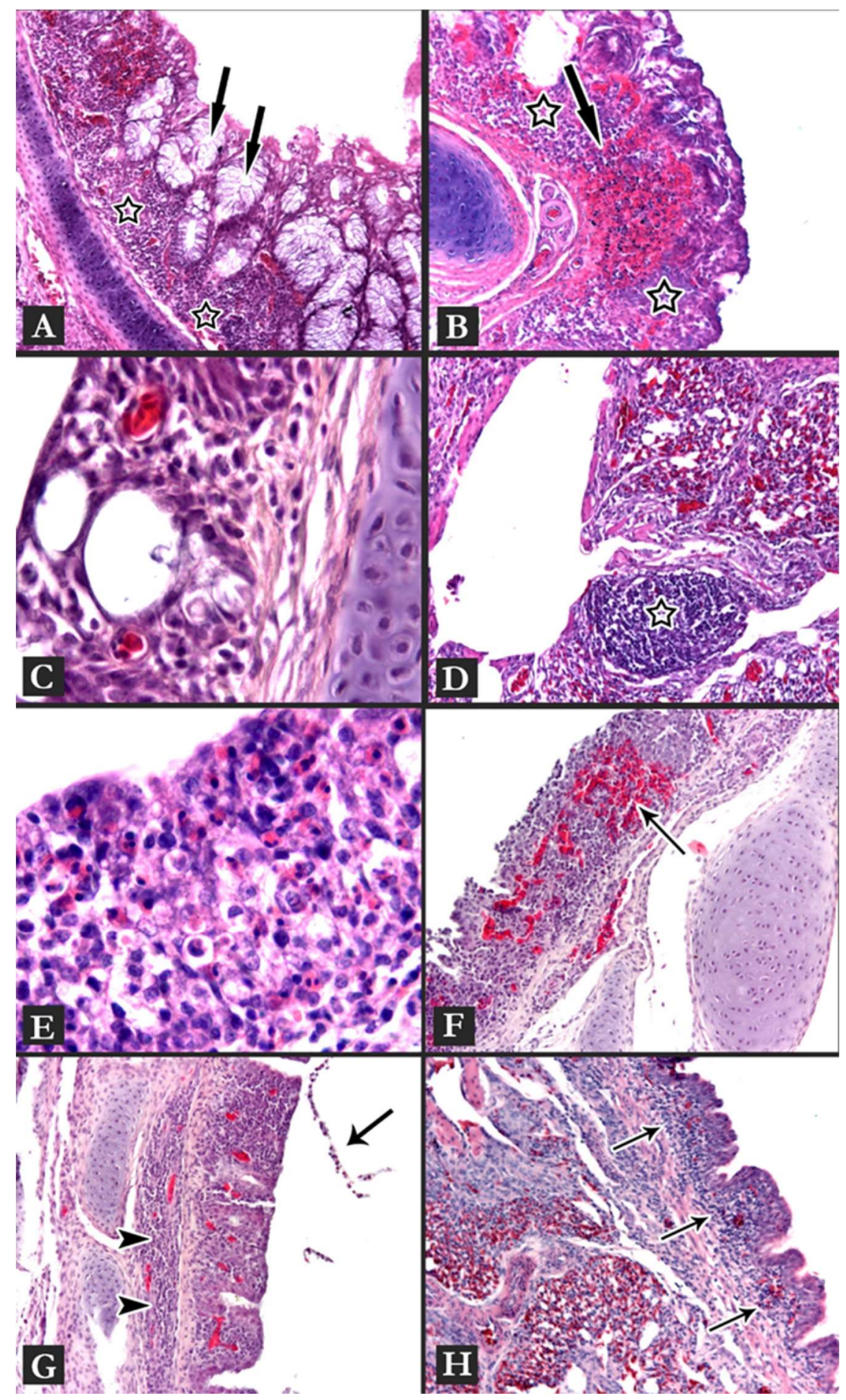

Figure-3. Group 1: (A) glands filled with secretion on the 5th day (arrows) and lymphocyte infiltration between the glands (stars), 10x. (B) diffuse hemorrhage in the propria (arrow) and lymphoid cell infiltration (stars) on the 5th day. 10x. (C) cystic structures in the epithelium on the 5th day, 40x. (D) lymphocytic focus in the interstitium on the 9th day (star), 10x. Group 2: (E) Diffuse heterophiles close to the lumen in the propria on 5th day, 40x; (F) lymphoid cell infiltration and hemorrhage in the propria on the 5th day (arrow), 10x. (G) heterophile leukocytes and ep fuse lymphoid cells in the propria and submucosa (arrowheads), 10x. $(\mathrm{H})$ diffuse lymphoid cells (arrows) and heterophile leukocytes around the primary bronchus on the 3rd day, 10x. 
Table-1. Histopathological findings according to degree and distribution at tissues of the experimental groups*.

\begin{tabular}{|c|c|c|c|c|c|c|c|c|c|c|}
\hline \multirow{2}{*}{$\begin{array}{l}\text { Experimental } \\
\text { Groups } \\
\\
\\
\stackrel{\infty}{0} \\
0 \\
0 \\
:-1\end{array}$} & \multicolumn{5}{|c|}{ Group I-(IBV-M41) } & \multicolumn{5}{|c|}{ GroupII-(IBV-B.avium) } \\
\hline & 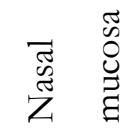 & 莺 & 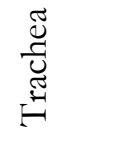 & $\underset{5}{\infty}$ & 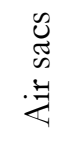 & 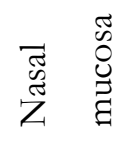 & 氙 & 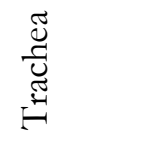 & 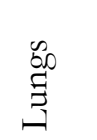 & $\begin{array}{l}\mathscr{U} \\
\tilde{W} \\
:\end{array}$ \\
\hline $2 \mathrm{DPI}$ & $1,2,3$ & $1,2,3,8$ & $2,5,8$ & 1,4 & 1,8 & $1,5,8$ & $1,5,8$ & $1,2,5,8$ & $1,5,9$ & 8 \\
\hline $3 \mathrm{DPI}$ & $5,6,7$ & $1,2,3,8$ & $2,5,6,8$ & 1,4 & 1,8 & $1,5,8$ & $1,4,5,8$ & $1,2,5,8$ & 6,8 & 8 \\
\hline $4 \mathrm{DPI}$ & $1,2,8$ & $2,3,7,8$ & 8 & $2,3,8$ & 1,8 & $2,5,6,8$ & $1,6,8,9$ & $1,2,6,8,9$ & 6,8 & 8 \\
\hline $5 \mathrm{DPI}$ & 1,8 & $2,3,7,8$ & $2,3,4,5$ & $2,3,8$ & 1,8 & $1,2,6,8$ & $1,6,8,9$ & $1,2,6,8,9$ & 1,6 & 8 \\
\hline $6 \mathrm{DPI}$ & $1,5,7,8$ & 3,8 & $2,3,4,5$ & 5,8 & 1,8 & $1,2,5,6,8$ & $1,6,8,9$ & $1,2,6,8,9$ & 1,6 & 8 \\
\hline $7 \mathrm{DPI}$ & 8,9 & 8 & 8 & 5,8 & 1,8 & $1,2,5,6,8$ & $1,6,8,9$ & $1,2,6,8,9$ & 6,9 & 8 \\
\hline $9 \mathrm{DPI}$ & 1,7 & 8 & 8,9 & 9,10 & 1,8 & $5,6,8$ & 5,9 & $1,2,6,8,9$ & 6,9 & 8 \\
\hline $11 \mathrm{DPI}$ & 5,8 & 8,9 & 8,9 & 8,9 & 1,8 & $5,6,8$ & 9 & $3,4,6$ & $5,6,8$ & 8 \\
\hline 13 DPI & 7 & 0 & 8,9 & 8,9 & 0 & $5,6,8$ & 9 & $3,4,8$ & $5,6,8$ & 8 \\
\hline 15 DPI & 8,9 & 0 & 9 & 8,9 & 0 & 8 & 8,9 & $3,4,8$ & 0 & 0 \\
\hline 18 DPI & 0 & 0 & 0 & 0 & 0 & 8,9 & $8,9,10$ & $4,8,9$ & 0 & 0 \\
\hline
\end{tabular}

Tablekey finding (0), Hyperemia and edema (1), Degeneration and desquamation (2), Dilatation and cysts in glands (3), Secretion in glands and Goblet cells (4), Heterophil leucocyte infiltration (5), Mononuclear cell infiltration (6), Diffuse lymphocytic infiltration (7), Focal lymphocytic infiltration (8), Regeneration and hyperplasia (9), Reparation including fibrosis (10).

*Since no lesions were seen in groups 3 and 4 , they were not included in the table.

\section{Immunohistochemical Findings}

In Group 1, immunoperoxidase staining displayed reddish-brown colored granular or diffuse immunopositive viral antigens in the mucosa of the glands and the nose, larynx, and trachea in different extents between the 2 nd and 7 th days of infection. A similar but less prominent immunopositivity was determined in the epithelial cytoplasm of the primary secondary bronchi in the lungs between the 5 th and 7th days. Immunofluorescence staining revealed shiny yellowish-green colored IF-positive viral antigens with a granular structure on a pale green ground in the epithelium of the nose, larynx, trachea, and primary/secondary bronchi between the 2 th and 7 th days. Furthermore, diffuse IF-positively viral antigens were determined in the glandular epithelia opening to the mucosa of these organs (Figure-4). 


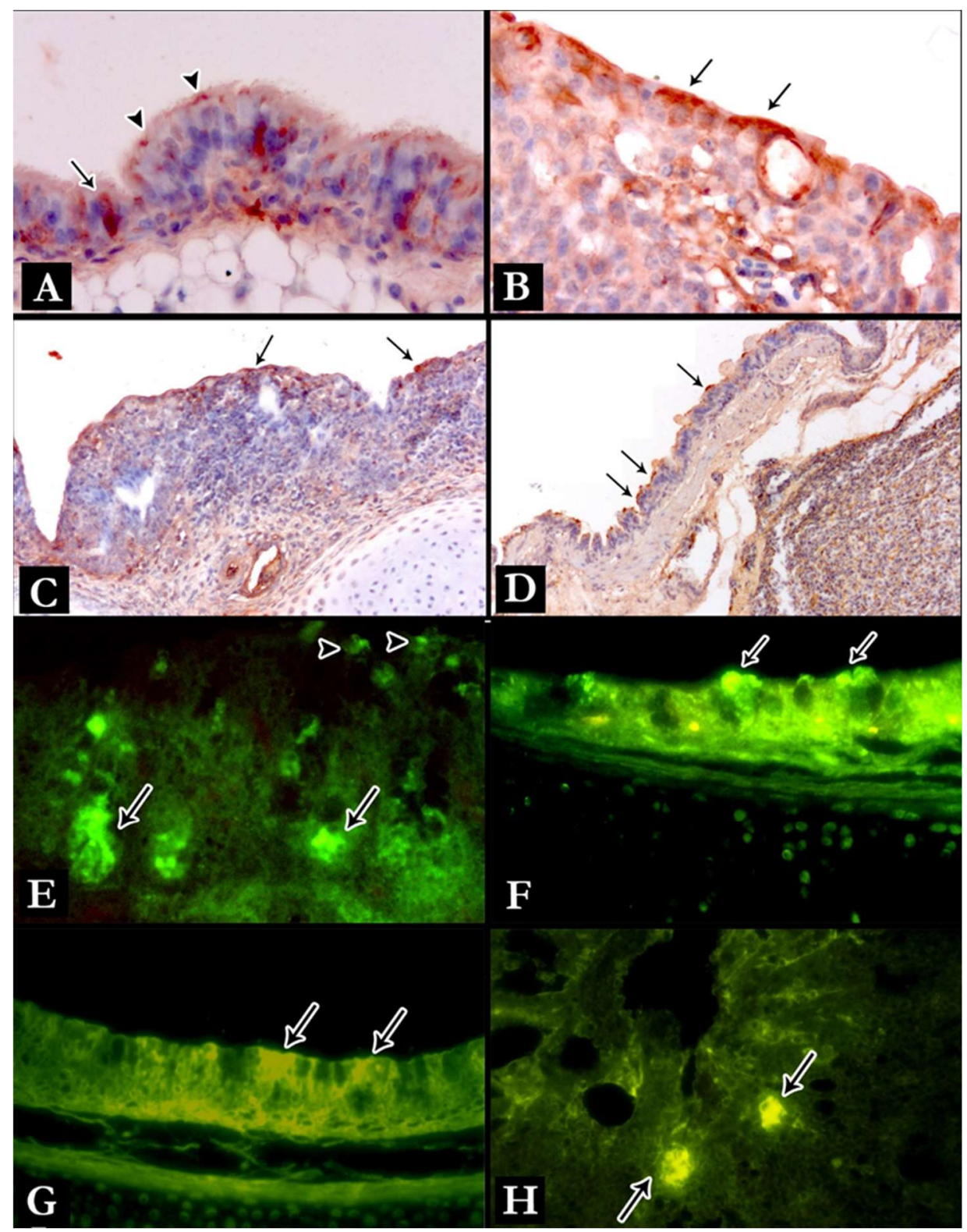

Figure-4.IB infection: ABC-peroxidase staining for the IB virus (A-D) and IB infection: Immunofluorescence staining for the IB virus (E-H). A: granular (arrowheads) or diffuse (arrow) IP-positive viral antigens in the nasal mucosa epithelium on the 2nd day, 40x. B: diffuse (arrows) IP-positive viral antigens in the laryngeal mucosa epithelium on the 3rd day, 40x. C: IP-positive viral antigens (arrows) in the laryngeal mucosa epithelium on the 5th day, 20x. D. IP-positive viral antigens (arrows) in the primary bronchial epithelium in the lungs on the 5th day, 10x. E: IF-positive viral antigens in the gland epithelium (arrows) and the nasal mucosa epithelium (arrowheads) on the 2nd day, 30x. F: IF-positive viral antigens in the tracheal mucosa epithelium (arrows) on the 2nd day, 30x. G: Diffuse IF-positive viral antigens in the tracheal mucosa epithelium on the 5th day (arrows), 30x. H: IF-positive viral antigens in the primary bronchial glands in the lungs on the 5th day (arrows), 25x.

In Group 2, in chicks with mixed infection caused by IBV and B. avium, IP staining showed reddish-brown granular or diffuse immunopositive viral antigens in various extents in the cytoplasm of the mucosa and gland epithelium of the nose, larynx, and trachea after the inoculation of IBV between the 2 nd and 11 th days. While the staining was weak and granular between the 2nd and 4th days, denser and more diffuse immunopositive fields in various sizes were noticed in the partially destructed tracheal mucosa epithelium between 5 th and 9 th days. Furthermore, we determined granular immunopositive viral antigens in the laryngeal mucosa epithelium between the 5th and 9th days and in the epithelial cytoplasm of the primary or secondary bronchi between the 7th and 11th days. In Group 2, the IF staining showed shiny yellowishgreen colored granular IF-positive viral antigens on a pale green ground in the epithelium of the nose, larynx, trachea and primary and secondary bronchi between the 2nd and 9th days. We observed also diffuse IFpositive viral antigens in the glandular epithelium of these organs opening to the mucosa (Figure-5). 


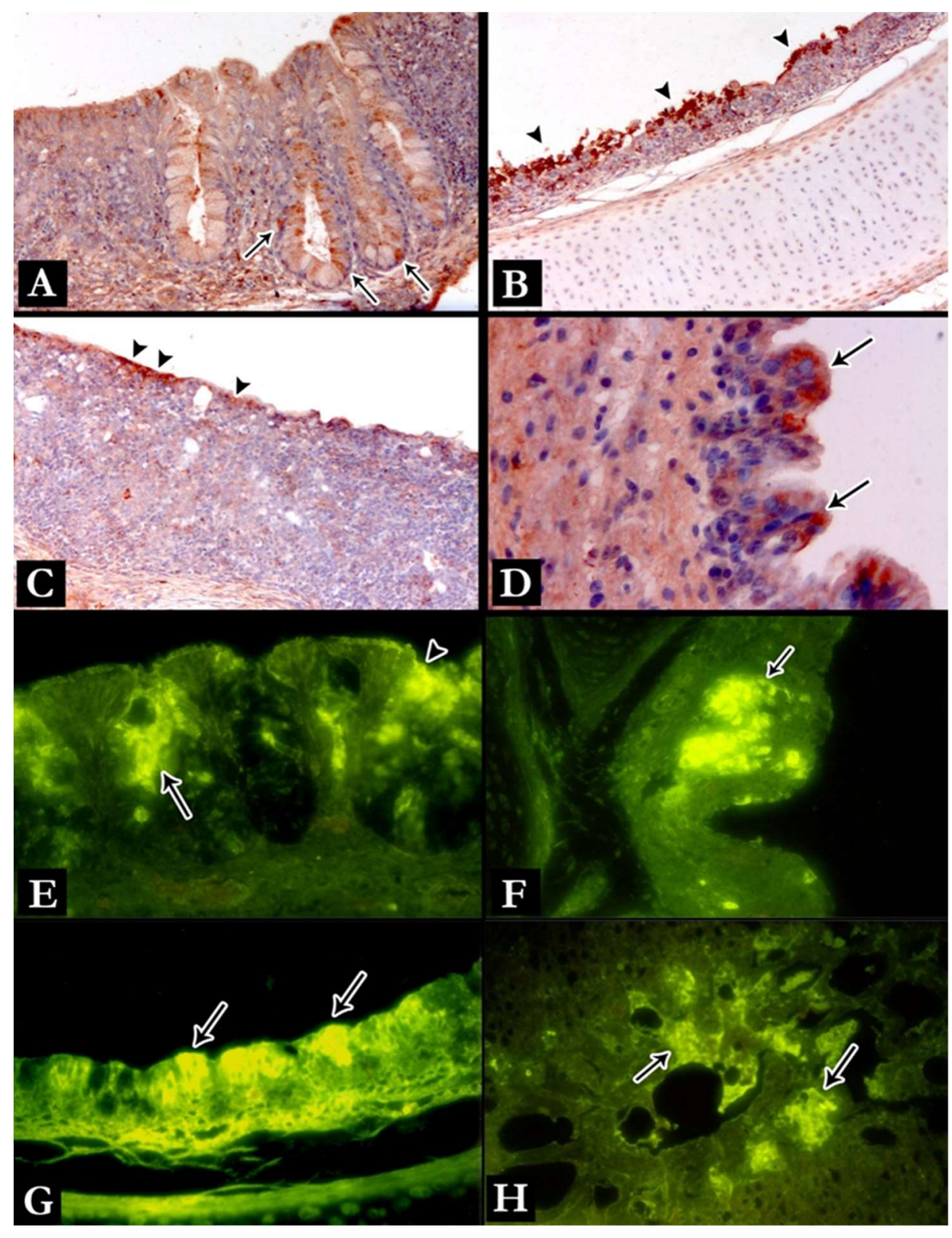

Figure-5. Mixed infection caused by IBV and B. avium: ABC-peroxidase staining for the IB virus. A: Viral antigens in the gland epithelium of the nasal mucosa on the 4th day, 20x. B: Viral antigens with diffuse distribution (arrows) in the partially intact tracheal mucosa epithelium on the 5th day, 10x. C: Granular viral antigens (arrowheads) in the laryngeal mucosa epithelium on the 7th day, 10x. D: Viral antigens in the some parts of the epithelium of the primary bronchus in the lungs on the 11th day, 40x. Mixed infection caused by IBV and B. avium: Immunofluorescence staining for the IB virus. E: IF-positive viral antigens in the gland epithelium (arrow) and mucosa epithelium (arrowhead) of the nose on the 4th day, 30x. F: IF-positive viral antigens in the laryngeal glands (arrow) on the 5th day, 30x. G: Diffuse IF-positive viral antigens in the tracheal mucosa epithelium (arrows) on the 5th day, 30x. H: IF-positive viral antigens in the glands of the primary bronchi on the 9th day, $25 \mathrm{x}$.

\section{DISCUSSION}

IBV is a virus that causes respiratory system problems in chickens at every age and may lead to morbidities and mortality (Cavanagh and Naqi 2003). In this study conducted on non-SPF chicks, the respiratory system of the neonatal chicks exhibited different responses with Bordetella avium, which is an obligate commensal, due to the immune system deficiency. More severe reactions were usually observed in coinfections. It was determined that co-infection affects significantly and diffusely the lower respiratory tract along with the upper respiratory tract. In addition, the comparison of the changes in the antigenic distribution of the agents showed that regenerative processes were prolonged in all parts of the respiratory system in the animals inoculated with both M-41 and B. avium compared to the animals inoculated only with M-14 strain. 
The studies focused only on IBV, were usually conducted with SPF chicks (Purcell and Mcferran, 1972, Smith et al 1985, Nakamura and al 1991, Raj and Jones 1997) and there was no study conducted with non-SPF chickens. Several studies reported that $B$. avium was mainly responsible for turkey coryza (Jackwood and Saif 2003) and did not directly lead to infection in healthy chickens (Montgomery et al 1983, Jackwood et al 1995) and participated mostly in infections caused by other pathogenic bacteria and viruses (Simmons et al 1978, Montgomery et al 1983). We did not find any other experimental study focused on both IBV and B. avium, except for two studies, in which the IB vaccine was investigated (Montgomery et al 1983, Jackwood et al 1995). Thus, in this study, we investigated the clinical, macroscopic, and microscopic findings of the infection models created with the intranasal inoculation of IBV-M41 strain and B. avium in the 15-day-old commercial, layer chicks in four separate groups and tried to elucidate the pathogenesis. It was demonstrated that the macroscopic findings of infectious bronchitis in the respiratory system became prominent between the 2nd and 9th days and seromucous exudate developed in the laryngeal, tracheal, and nasal mucosa in these days along with edema and hyperemia (Purcell and Mcferran 1972, Purcell et al 1976). It was also reported that non-glossy appearance in the air sacs and local hyperemia in the lungs might accompany these macroscopic findings (Purcell and Mcferran 1972, Raj and Jones 1997). In our study, the prominent findings observed in Group 1 between the 4th and 9th days were similar to the findings reported in the literature. The findings were prominent in Group between 5th and 15th days and with the difference of Group 1, hemorrhage in the nasal mucosa and a more mucoid exudate were observed in the nasal cavity. These findings were consistent with the findings of the bordetellosis studies, namely hyperemia in the nasal and tracheal mucosa lasting approx. 2 weeks and the seromucous exudate seen in the cavities of these organs (Arp and Cheville 1984, Van Alstine and Arp 1988, Jackwood et al 1995). However, the findings related to the collapse due to the softening of the tracheal cartilage (Arp and Cheville 1984, Van Alstine and Hofstad 1985), which was reported for bordetellosis, was not encountered in this group.

The investigators focused particularly on the respiratory system in IB disease and mentioned that lesions were localized mainly in the trachea but also seen in the nose, lung, and air sacs (Garside 1965, Purcell and Mcferran 1972, Goryo et al 1984, Nakamura et al 1991, Raj and Jones 1997, Matyhjis et al 2003). The observation of severe findings in both groups in the nose, larynx, trachea, and lungs and air sacs of 10 chicks confirmed this suggestion. In our study, in Group 1, the microscopic nasal lesions were observed in two periods. In the first period (between the 3rd and 9th days), the characteristics of acute rhinitis were presented mainly with epithelial degeneration-regeneration and lymphoid cells in the nasal mucosa. In the second period (between the 9th and 15th days), accumulated lymphoid cells were observed in follicles in the propria mucosa and full regeneration in the mucosa epithelium. In Group 2, a lymphoid cell infiltration developed between the 3rd and 6th days after the IBV inoculation. Heterophilic cells jointed these cells and an appearance consistent with rhinitis characterized by the descent of these cells to the maxillary salivary glands developed. In the last period between the 13th day and the end of the experiment, the findings were similar to the previous group. Lymphoid cell foci and epithelial regeneration dominated again the picture. In our study, the findings of Group 1 were consistent with the findings reported by Purcell and McFerran (1972). However, the findings in Group 2, heterophile leukocyte infiltration and prolonged acute infection period were different from the findings observed in IB. These findings were consistent with the classical findings of bordetellosis (Simmons et al 1978, Saif et al 1980).

In studies focused on the infectious bronchitis virus strains, which are active on the respiratory system, the trachea was the main target of research (Purcell and Mcferran 1972, Purcell et al 1976, Ducatelle et al 1984, Nakamura et al 1996, Chousalkar et al 2007). In this study, two days after the inoculation of IBV to the trachea and larynx, findings characterized by the loss of cilium in the epithelial cells, hydropic degeneration, hyperemia in the propria, and mild lymphoid cell infiltration emerged. In the following days, microscopic bleedings, diffuse lymphoid cell infiltration due to the mucosal thickening, and thinning in the epithelium were added to the existing findings and this picture continued until the 6th day. Then the findings started to regress. The epithelial cells, which had been flattened, regained their prismatic structure. Cilia re-appeared. Dense lymphoid cells diffusely distributed in the propria either gradually disappeared or formed follicle-like groups. On the 15th day, the mucosa re-gained almost completely its normal appearance. However, in Group 2 compared to Group 1 , a more severe and prolonged inflammatory process was observed in the trachea and larynx between the 2nd and 13th days. In addition to the Group 1 findings; we observed mucus in the lumen and exudate consisting of heterophile leukocytes between the 7 th and 11th days, bacteria colonies attached to the epithelium between 5 th and 7 th days, infiltration of heterophile leukocytes and diffuse lymphoid cells close to the lumen between the 5th and 13th days, and hyperplasia (up to 8-12 times) in the trachea between the 9th and 13th days, in the epithelial cells of the mucosa between the $3 \mathrm{rd}$ and $4 \mathrm{th}$ days. The findings observed in Group 1 were comparable to the findings reported by Garside (1965). In Group 2, an increase in the epithelial regeneration and inflammatory reactions as a response to the destruction caused by $B$. avium were observed. 
Some authors (Purcell and Mcferran 1972, Nakamura et 1996, Raj and Jones 1997) reported hyperplasia up to 4-5 times in the epithelial cells two days after the IBV infection. Firat (1995) related this multilayered appearance to the dense lymphoid infiltration under the mucosa epithelium and reported that they took the appearance of a stratified squamous epithelium as a result of side by side and one under the other arrangement of the epithelial cells. In this study, in Group 2, epithelial hyperplasia was prominent between the 9th and 13th days in 8-12 layers and these findings were interpreted as a reaction related to the delayed recovery due to the addition of $B$. avium to IB infection. The bacterial colonies, exudate in the lumen, and the heterophile leukocyte infiltration confirmed that $B$. avium participated in the infection. The delay of recovery about 1 one week was also interpreted in favor of the secondary infection. Besides, these findings were consistent with the microscopic findings suggested for bordetellosis in turkeys (Arp and Cheville 1984, Van Alstine and Hofstad 1985).

It was reported that infectious bronchitis had a milder course in the lungs compared to the organs of the upper respiratory system (Purcell and Mcferran 1972, Pohl 1974, Mcmartin 1993, Nakamura et al 1996, Raj and Jones 1997, Cavanagh and Naqi 2003). Likewise, bordetellosis cause also mainly lesions in the upper respiratory tract (Van Alstine and Hofstad 1985, Lister and Alexander 1986, Jackwood and Saif 2003). In our study, in both Group 1 and 2, the pulmonary findings were milder compared to the findings in the upper respiratory tract. In Group 1, hyperplasia that emerged in BALT two days after the inoculation worsened over the course of the experiment and obstructed almost the bronchial lumen between the 7th and 9th days. We noticed that the cilia of the epithelial cells in the secondary and primary bronchi became partly invisible after the 4th day and the lymphocytes located in the periphery of the lymphoid tissue spread towards the interstitium and formed central foci. In Group 2, nondense heterophile leukocytes and hemorrhage were added to the similar lesions between the 5th and 7th days and heterophile and mucoid lesions in the lumens of the primary bronchi between the 13th and 15th days. These recorded findings were consistent with the findings encountered in both diseases. In this study, mixed infections with either IBV or E. coli (Gross 1958, Gross 1961, Fabricant and Levine 1962, Purcell and Mcferran 1972, Dwars et al 2009) or air sac inflammation related to bordetellosis (Van Alstine and Arp 1987, El-Sukhon et al 2002) were encountered in Group 1 and Group 2 in 10 animals in the form of hyperemia and perivascular lymphoid cell infiltration. The immunohistochemical techniques are important for the diagnosis but also has a critical role in the determination of the pathogenesis during the infection period and the localization of the agent in the tissue (Chong and Apostolov 1982, Ambali and Jones 1990, Janse et al 1994, Chen and Itakura 1997). Owen et al. (1991) conducted a study on day-old chickens with IF and IP methods and reported that they could detect the agent in the tracheal epithelium, macrophages, and epithelial cells spilled into the lumen until 10th day after the inoculation. In a study conducted with dayold SPF chicks, after the inoculation, the agent was determined in the tracheal mucosa epithelium until the 11th day and in the lungs until the 7th day (Janse et al 1994). In another study, which was conducted with 10day and 21-day old SPF chicks from two different lines of the RIR race (C and 15I), the authors detected IBV antigen in the mucosa epithelium of the trachea until 7th day in the 10-day-old C-line chicks; until 5th day in the 21-day-old C-line chicks; until 12th day in the 10day-old 15I line chicks; and until 9th day in the 21-dayold 15I line chicks with the IP method (Nakamura et al 1991). Dwars et al (2009) detected viral antigens in the trachea in 28-day-old commercial chicks until 4th day after the IB virus inoculation. In our study, in Group 1, we detected viral antigen in the nose, larynx, trachea, and lungs in 15-day-old chicks with both IP and IF methods between the 2 nd and 7 th days and in light of these findings we believed that infection might have a different course in SPF and common animals and particularly age and racial sensitivity might have a role in this context. In Group 2, in which both agents (IBV and B. avium) were administered, the prolongation of antigen positivity performed with IP and IF methods until 11th day was associated with the effects of the secondary infection caused by B. avium. Indeed, in another study conducted on 14-day-old chicks infected with IBV and Infectious Bursal Disease Virus (IBDV), the virus was detected in the tracheal epithelium and gland epithelium until 6th day in the group infected only with IBV and this period was prolonged to 13thday in the group with additional IBDV inoculation (Chen and Itakura 1997).

In conclusion, the findings of this study pointed to increased morbidity in infected coops, as the IBV infection, which does not have high mortality in chicken, led more diffuse lesions without causing mortality in non-SPF chicks alone or in combination with an opportunistic agent like B. avium. We consider that serious yield loss and economic loss may emerge due to this disease, which can affect mainly the respiratory system along with the urogenital system. In this context, we recommend elimination of the risk factors related to hygiene, temperature, chemical-toxic exposures (formaldehyde fumigation, etc.), unbalanced nutrition, inadequate ventilation, and prevention of IBV infection and opportunistic agents like B. avium with prophylactic vaccination.

\section{ACKNOWLEDGEMENT}

This research was obtained from $\mathrm{PhD}$ Dissertation entitled as "Examination of Pathomorphological Findings in Experimental Infectious Bronchitis Virus M41 Strain and Bordetella avium in Chicks" (Graduate School of Health Sciences of Ankara University, 2010). 
This research was financially supported by the Afyon Kocatepe University Scientific Research Projects Coordination Unit (Project no:07VF05)

Ankara University Faculty of Veterinary Medicine Ethics Committee decided that this study is in accordance with the "Ethics Committee Directive"(decision number: 23, 23 May 2006).

\section{Conflict of Interest}

The authors declared that there is no conflict of interest.

\section{REFERENCES}

Ambali AG, Jones RC. Early pathogenesis in chicks of infection with an enterotropic strain of infectious bronchitis virus. Avian Dis. 1990; 34: 809-817.

Arp LH, Cheville NF. Tracheal lesions in young turkeys infected with Bordetella avium. Am J Vet Res. 1984; 45: 2196-2200.

Benyeda Z, Szeredi L, Mató T, Süveges T, Balka G, AbonyiTóth Z, Rusvai M, Palya V. Comparative histopathology and immunohistochemistry of QX-like, Massachusetts and $793 / B$ serotypes of infectious bronchitis virus infection in chickens. J Comp Pathol. 2010 Nov;143(4):276-83.

Bilgehan H. Klinik Mikrobiyolojik Tanı. 4. baskı. İzmir Şafak Matbaacilık.2004. Bölüm 7: 131-144.

Blackall PJ, Doheny CM. Isolation and characterisation of Bordetella avium and related species and an evaluation of their role in respiratory disease in poultry. Aust Vet J. 1987; 64: 235-238.

ButcherGD, Winterfield RW, Shapiro DP. Pathogenesis of H13 nephropathogenic infectious bronchitis virus. Avian Dis. 1990; 34: 916-921.

Bwala DG, Solomon P, Duncan N, Wandrag DBR, Abolnik C. Assessment of Mycoplasma gallisepticum vaccine efficacy in a co-infection challenge model with QX-like infectious bronchitis virus. Avian Pathol. 2018;47(3):261-270.

Cavanagh D. Severe acute respiratory syndrome vaccine development experiences of vaccination against avian infectious bronchitis coronavirus. Avian Pathol. 2003; 32: 567-582.

Cavanagh D, Naqi SA. Infectious Bronchitis. In: Poultry Disease. 2003; Chapter 3. 11th ed. Saif YM, Barnes HJ, Fadly AM, Glisson JR, Mcdougald LR, Swayne DE, eds. Iowa: Iowa State University Press, 2003.

Cavanagh, D. \& Gelb, J., 2008, "Infectious bronchitis" in Y.M. Saif, A.M. Fadly, J.R. Glisson, L.R. Mcdougald, L.K. Nolan \& D.E. Swayne (eds.), Diseases of poultry, p. 117-135, Wiley-Blackwell, Ames.

Chen BY, Itakura C. Histopathology and immunohistochemistry of renal lesions due to avian infectious bronchitis virus in chicks uninoculated and previously inoculated with highly virulent infectious bursal disease virus. Avian Pathol, 1997; 26: 607-624.

Chong KI, Apostolov K. The pathogenesis of nephritis in chickens induced by infectious bronchitis virus. J Comp Pathol. 1982; 92: 199-211.

Chousalkar KK, Roberts JR, Reece R. Histopathology of two serotypes of infectious bronchitis virus in laying hens vaccinated in the rearing phase. Poultry Sci. 2007; 86: 5962.

Raj GD, Jones RC. Infectious bronchitis virus: Immunopathogenesis of infection in the chicken. Avian Pathol. 1997; 26: 677-706.

Ducatelle R, Meulemans G, Coussement W, Hoorens J. Aetio-pathology of the fowl trachea early after inoculation with H52 infectious bronchitis virus. J Vet Med B. 1984; 31:151-160.

Dwars RM, Matthijs MGR, Daemen AJJM, Van Eck JHH, Vervelde L, Landman WJM. Progression of lesions in the respiratory tract of broilers after single infection with Escherichia coli compared to superinfection with E. coli after infection with infectious bronchitis virus. Vet Immunol Immunop. 2009; 127: 65-76.

El-Sukhon SN, Musa A, Al-Attar M. Studies on the bacterial etiology of air sacculitis of broilers in northern and middle Jordan with special reference to Escherichia coli, Ornithobacterium rbinotracheale, and Bordetella avium. Avian Dis. 2002; 46: 605-612.

Fabricant J, Levine PP. Experimental production of complicated chronic respiratory diseaseinfection ('air sac' disease). Avian Dis. 1962; 6: 13-23.

Fernando F, Montassier MFS, Silva KR, MFS, Okino CH, de Oliveira, ES, Fernandes CC, Bandarra, MB, Goncalves, Borzi MM, Santos RM, Vasconcelos R, Alessi AC, Montassier H. Nephritis Associated with a S1 Variant Brazilian Isolate of Infectious Bronchitis Virus and Vaccine Protection Test in Experimentally Infected Chickens. Int J Poult Sci. 2013;12;639-646.

Fırat İ. İnfeksiyöz bronşitis virusunun üç patojen susu ile enfekte edilen civcivlerdeki nefrolojik bulguların histopatolojik karşılaştırılması. İstanbul Üniversitesi Sağlık Bilimleri Enstitüsü Doktora Tezi. 1995

Garside JS. The histopathological diagnosis of avian respiratory infections. Vet Rec. 1965; 27:354-356.

Goryo M, Umemura T, Itakura C. Concurrence of nephrosisnephritis due to infectious bronchitis virus and infectious bursal disease in broiler chickens. Avian Pathol. 1984; 13: 191-200.

Gross WB. Symposium on chronic respiratory diseases of poultry. II. The role of Escherichia coli in the cause of chronic respiratory disease and certain other respiratory diseases. Am J Vet Res. 1958; 19: 448-452.

Gross WB. The development of "air sac disease." Avian Dis. 1961; 5:431-439.

Jackwood MW, Mc Carter SM, Brown TP. Bordetella avium: An opportunistic pathogen in Leghorn chickens. Avian Dis. 1995; 39: 360-367.

Jackwood MW, Saif YM. Bordetellosis. In: Poultry Disease, chapter 21. 11th ed. Saif YM, Barnes HJ, Fadly AM, Glisson JR, Mcdougald LR, Swayne DE, eds. Iowa: Iowa State University Press, 2003.

Jackwood, M. W., and S. de Wit. Infectious bronchitis. In: Diseases of poultry, 13th ed. D. E. Swayne, J. R. Glisson, L. R. McDougald, L. K.Nolan, D. L. Suarez, and V. Nair, eds. John Wiley and Sons, Inc., Ames, IA. pp. 139-159. 2013.

Janse EM, Van Roozelaar D, Koch G. Leukocyte subpopulations in kidney and trachea of chickens infected with infectious bronchitis virus. Avian Pathol. 1994; 23: 513-523.

Kinde H, Daft B, Castro AE, Bickford AA, Gelb J, Reynolds B. Viral pathogenesis of a nephrotropic infectious bronchitis virus isolated from commercial pullets. Avian Dis. 1991; 35: 415-421.

King, A.M.Q., Adams, M.J., Carstens, E.B. \&Lefkowitz, E.J. (eds.), 2012, Virus taxonomy - Ninth report of the International Committee on Taxonomy of Viruses, Elsevier, London.

Lister SA, Alexander DJ. Turkey rhinotracheitis: A rewiew. Vet Bull. 1986; 56: 633-663.

Liu P, Deng G, Guo XQ, et al., 2015. Clinicopathology of gout in growing layers induced by avian nephrotrophic strains of infectious bronchitis virus. Pak Vet J. 2015; 35:345-9. 
Luna LG. Routine Staining Procedures. Manual of Histologic Staining Methods of the Armed Forces Institute of Pathology. New York: McGraw-Hill. 1968, 32-47.

Matthijs MGR, Van Eck JHH, Landman WJM, Stegeman JA. Ability of Massachusetts-type infectious bronchitis virus to increase colibacillosis susceptibility in commercial broilers: A comparison between vaccine and virulent field virus Avian Pathol. 2003; 32: 473-481.

Mcmartin DA. Infectious Bronchitis. In: Virus Infections of Vertebrates. Virus Infections of Birds. Vol 4. Mcferran JB, Mccnulty MS, eds. Amsterdam: Elsevier Science, 1993. 249-275.

Montgomery RD, Kleven SH, Villegas P. Observations on the pathogenicity of Alcaligenes faecalis in chickens. Avian Dis. 1983; 27: 751-761.

Nakamura K, Cook JKA, Otsuki K, Huggins MB, Frazier JA. Comparative study of respiratory lesions in two chicken lines of different susceptibility infected with infectious bronchitis virus: Histology, ultrastructure and immunohistochemistry. Avian Pathol. 1991; 20: 241-257.

Nakamura K, Imai K, Tanimura N. Comparison of the effects of infectious bronchitis and infectious laryngotracheitis on the chicken respiratory tract. J Comp Pathol. 1996; 114: 11-21.

Odugbo MO, Musa U, Ekundayo SO, Okewole PA, Esilonu J. Bordetella avium infection in chickens and quail in Nigeria: Preliminary investigations. Vet Res Commun. 2006; 30: 15.

Owen RL, Cowen BS, Hattel AL, Naqi SA, Wilson RA. Detection of viral antigen following exposure of one-dayold chickens to the Holland 52 strain of infectious bronchitis virus. Avian Pathol. 1991; 20: 663-673.

Pohl R. The histopathogenesis of the nephrosis-nephritis syndrome. Avian Pathol. 1974; 1: 1-13.

Purcell DA, Mcferran JB. The histopathology of infectious bronchitis in the domestic fowl. Res Vet Sci. 1972; 13: 116122.

Purcell DA, Tham VL, Surman PG. The histopathology of infectious bronchitis in fowls infected with a nephrotropic "T" strain of virus. Aust Vet J. 1976; 52: 85-91.

Reed L, Muench H. A simple method of estimating fifty percent end points. Am. J. Hyg. 1939;27: 493-497.

Saif YM, Moorhead PD, Dearth RN, Jackwood DJ. Observations on Alcaligenes faecalis infection in turkeys. Avian Dis. 1980; 24: 665-684.

Sainte-Marie G. A paraffin embedding technique for studies employing immunofluorescence. J Histochem Cytochem, 1962; 10: 250-256.

Schulz LC. Krankheiten und Syndrome. In: Pathologie der Haustiere Teil II. Germany. 1991,222-224.

Simmons DG, Gray JG, Rose LP. Isolation of an etiologic agent of acute respiartory disease (Rhinotracheitis) of turkey poults. Avian Dis. 1978; 23: 195-203.

Smith HW, Cook JKA, Parsell ZE. The experimental infection of chickens with mixture of infectious bronchitis virus and Escherichia coli. J Gen Virol. 1985; 66: 777-786.

Van Alstine WG, Hofstad MS. Antibiotic aerolization: The effect on experimentally induced alcaligenes rhinotracheitis in turkeys. Avian Dis. 1985; 29: 159-176.

Van Alstine WG, Arp LH. Effects of Bordetella avium infection on the pulmonary clearance E. coli in turkeys. Am J Vet Res. 1987; 48: 922-926.

Van Alstine WG, Arp LH. Histologic evaluation of lung and bronchus-associated lymphoid tissue in young turkeys infected with Bordetella avium. Am J Vet Res. 1988; 49: 835839

Valastro, V., Holmes, E.C., Britton, P., Fusaro, A., Jackwood, M.W., Cattoli, G. and Monne, I. S1 gene-based phylogeny of infectious bronchitis virus: An attempt to harmonize virus classification. Infect Genet Evol. 2016; 39: 349-364. 